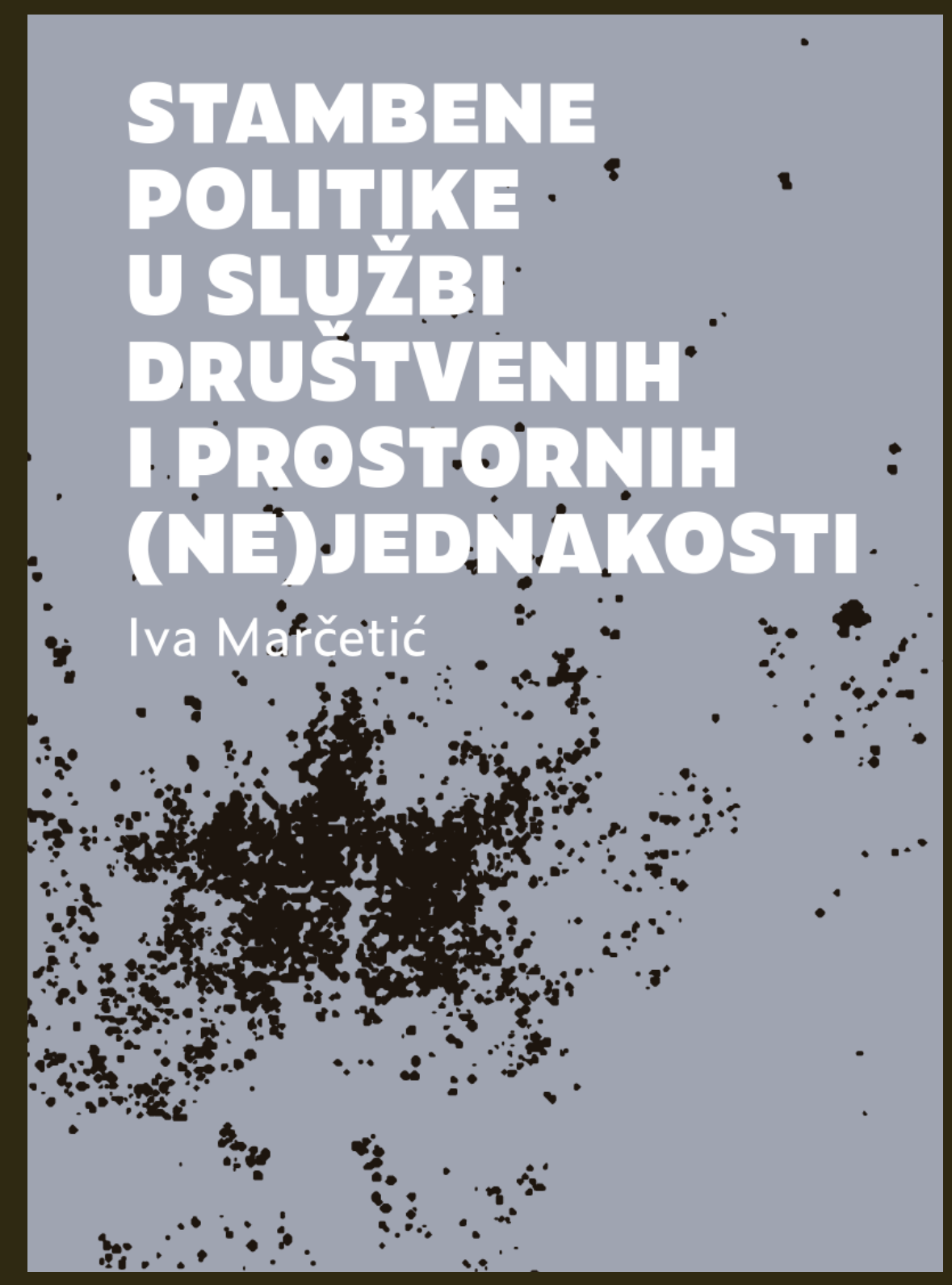




\section{PREMA KOLEKTIVNOM ODGOVORU NA STAMBENO PITANJE}

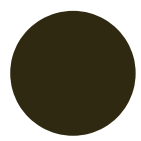

Iva Marčetić. Stambene politike u službi društvenih i prostornih (ne)jednakosti. Zagreb: Pravo na grad, 2020. ISBN 978-953-49340-0-5

DOI: $10.31664 /$ zu.2020.107.10

U državi u kojoj je prosječna neto plaća nešto manja od šest tisuća kuna, a prosječni kvadrat stana košta dvije tisuće eura, nije potrebno puno objašnjavati zašto je knjiga udruge Pravo na grad autorice Ive Marčetić vrijedno i važno štivo. Indikativna naslova Stambene politike u službi društvenih i prostornih (ne) jednakosti, knjiga u svojoj dalekosežnosti započinje analizom razdoblja Kraljevine Jugoslavije, imajući u vidu kako su trenutačne mogućnosti ostvarenja prava na stan posljedica prijašnjih, povijesnih stambenih politika: prostorne nejednakosti nisu tu od jučer.

Knjiga pojašnjava sam termin „prava na stan” utoliko što ga neoliberalni narativ, iskovan pod utjecajem tačerskog recepta, vješto iskrivljava svodeći ga isključivo na pitanje individualnog prava na vlasništvo. Aktualna sveprisutna nepristupačnost stambenog prostora, popraćena beskućništvom i drugim individualnim i kolektivnim tragedijama, prouzročena je upravo ideologijom komodifikacije najvećeg udjela stambenih jedinica, gdje se postupnim prepuštanjem stambenog pitanja bankama i slobodnom tržištu u paketu prodalo i samo naše pravo na stan. S time u vidu, bilo bi krivo reći kako stambene politike ne postoje jer itekako postoje, ali gotovo isključivo kao dio prethodno spomenute agende koja se svodi na povlačenje države iz proizvodnje stambenog prostora i paralelno poticanje financijskih institucija da ostvare profit i u ovom segmentu života.
Iva Marčetić. Stambene politike u sluzbbi društvenih i prostornih (ne)jednakosti. Zagreb: Pravo na grad, $202 \mathrm{O}$.

$\leftarrow$

\section{Filip Pračić}

Samostalni istraživač, Zagreb 
Ne skrivajući činjenice određenih nepravdi dodijele stanova na temelju obrazovnog i profesionalnog statusa, knjiga statistički pokazuje da je u socijalističkoj Jugoslaviji ostvaren impresivan stambeni fond. Nadalje, razbijen je i mit o dobrovoljnosti privatizacijskog procesa: na temelju istraživanja Ognjena Čaldarevića, vidljivo je da je pristanak bio iz nužde, odnosno da je bio posljedica izostanka ikakvih alternativa te popraćen gašenjem institucija zaduženih za proizvodnju i dodjelu društvenih stanova. Iva Marčetić zapravo kreće od teze kako je konkretna stambena situacija uvijek ishod preplitanja globalnih i lokalnih putanja. Pišući tako o privatizacijskom procesu u doba tranzicije, bitno je spomenuti kako je u našem lokalnom slučaju bila prisutna i politika etničkog čišćenja. Knjiga navodi kako je, prema izvještaju specijalne izvjestiteljice Ujedinjenih naroda, procijenjeno da je čak oko sto tisuća bivših nositelja stanarskog prava uskraćeno za mogućnost otkupa stana. Većina njih bili su pripadnici srpske ili drugih nacionalnih manjina, a ta je uskrata bila omogućena izmjenama Zakona o otkupu stanova tijekom ratnih godina.

Još jedno zanimljivo opažanje tiče se premještanja stambenog pitanja u domeni demografije, kao odgovora na masovno iseljavanje mladih nakon ulaska Hrvatske u Europsku uniju. Promjene u političkom narativu tako su dovele do toga da Agencija za pravni promet i posredovanje nekretninama na svojim mrežnim stranicama broji djecu rođenu u njihovim stanovima, poput kakve teladi, srozavajući ideju stambenog prostora na stroj za rađanje, umjesto da se učinkovitost politika stambenog subvencioniranja mjeri parametrima ekonomičnosti i stambene sigurnosti.

Lekcija neoliberalizma jasna je i tmurna: stambeno pitanje zahtijeva odgovor u vidu osiguravanja velikog broja javnih, odnosno društvenih stambenih jedinica kolektivnim sredstvima. Pravo na stan mora biti dio naše zajedničke moći utjecanja na materijalne uvjete života.

U suprotnome, osuđeni smo na čitav spektar individualnih borbi i patnji, od tragedija deložacija i beskućništva, do suludog zaduživanja i kamatnog ropstva. Danas, kada se čitava jedna generacija ne može emancipirati uslijed suludo visokog troška stanovanja, jasno je da pitanje dekomodifikacije stanovanja postaje prioritetno. A iščitavajući ovu knjigu pravci dekomodifikacije stambenih politika postaju evidentni: ulaganje u izgradnju javno-najamnog fonda baziranog na realnim potrebama i inkluzivnog spram različitih društvenih skupina, prostorno lociranje tog istog fonda na način da se spriječi gentrifikacija, ulaganje u mogućnost neprofitne izgradnje stambenog prostora i regulacija najma na tržištu.

Time što je kapitalizam preuzeo dominaciju u proizvodnji prostora, uporno je usmjerava upravo na onaj način koji mu osigurava neprekidno održavanje odnosa na kojima se temelji. Kako je danas neoliberalni kapitalizam sve agresivniji, tako je i oštri sukob s njegovom suvremenom zbiljom sve nužniji. Trebaju li u takvom sukobu arhitektura i urbanizam biti tek tihi promatrači ili njihova priroda društvene discipline iziskuje da se stane na stranu većine istog tog društva?

Pristupačno stanovanje za sve predstavlja možda sljedeći najveći korak u dugoj povijesti emancipacijske borbe. Taj korak mora i može doći jedino kroz pritisak koji će arhitekti i urbanisti, ali i svi ostali građani, vršiti na postojeći barbarizam nevidljive ruke tržišta koji je nastupio zbog nepostojanja adekvatnih stambenih politika. Riječima sociologa Henri Lefebvrea: „Ni arhitekt niti urbanist, ni sociolog niti ekonomist, ni filozof ili politika ne mogu iz ništavila dekretom izvući nove oblike i odnose. (...) Samo grupe, klase ili frakcije društvenih klasa sposobne za revolucionarne inicijative mogu preuzeti odgovornost i rješenja urbanih problema odvesti do potpunog izvršenja; obnovljeni grad bit će djelo takvih društvenih i političkih snaga." Je li na rasporedu vrijeme da se arhitektonska struka razbudi iz apolitičnog drijemeža i nadiđe vlastiti status quo? Ideja stambene arhitekture koja nije diktirana zakonima uskogrudnog individualizma predstavlja vjerojatno najveći korak u tom nadilaženju. 
Knjiga Ive Marčetić predstavlja do sada najiscrpniji prostorno-analitički uvid u posljedice stambenih politika na području Zagreba. Činjenica da je istraživanje ovog obima, stručnosti i bitnosti dobrovoljno provela građanska udruga, a ne nadležne gradske i/ili državne institucije, istodobno je pohvalna za prve i sramotna za ove druge, ali samim time dodatno svjedoči o nužnosti prethodno spomenutog „preuzimanja stvari u naše ruke”: bolje stambene politike neće se stvoriti same od sebe.

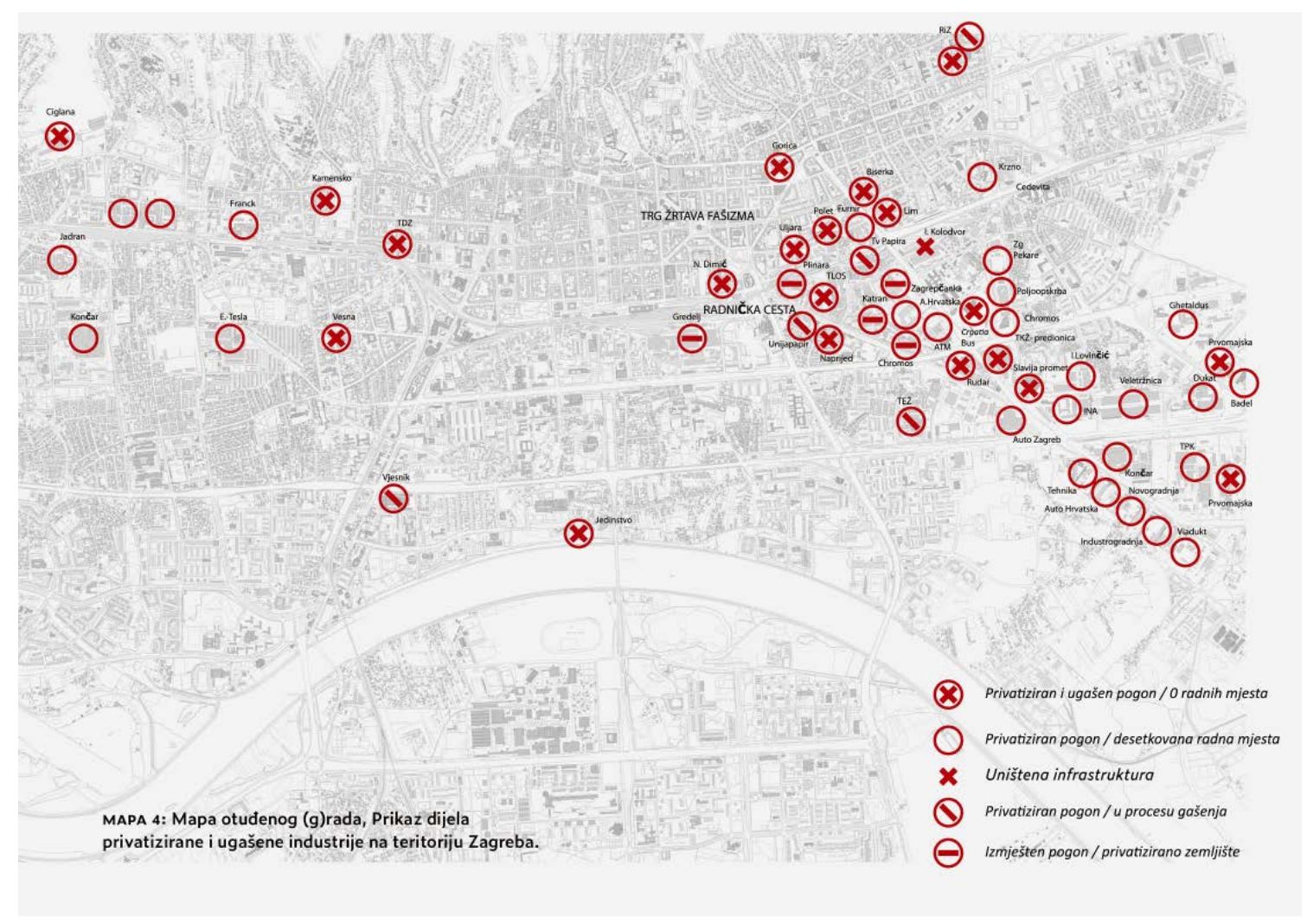

